\title{
Penataan Sistem Pelabuhan Rakyat di Pelabuhan Tambak Lorok Semarang
}

\author{
Sutini $^{\mathbf{a}^{*}}$ \\ ${ }^{a}$ Universitas Maritim AMNI Semarang \\ a*Email: paleon_sutini@yahoo.co.id
}

\begin{abstract}
ABSTRAK
Penelitian ini terutama ditujukan untuk memperbaiki sistem layanan utama dalam pelabuhan rakyat tentang pengiriman barang, dokumen kapal dan dokumen muatan. Ini memetakan dimensi kualitas layanan ke serangkaian karakteristik layanan baru berdasarkan prioritas terbaru dari perusahaan pelayaran rakyat di Pelabuhan Tambak Lorok. Data yang dikumpulkan melalui survei ke perusahaan pelayaran rakyat dan pelabuhan rakyat yang ada di Semarang yaiu Pelabuhan Tambak Lorok sebagai objek penelitian dan melalui metode regresi di dalam model regresi linier ini yang mana regresi linier menggunakan satu variabel untuk menjelaskan atau memprediksi hasil dari data penelitian di penataan sistem pelabuhan rakyat di Pelabuhan Tambak Lorok Semarang. Hasil menunjukkan bahwa tiga karakteristik teratas yang mempengaruhi pelayanan dan penataan di pelabuhan yaitu (1) kualitas layanan pada pada kapalkapal pada pelabuhan rakyat Pelabuhan Tambak Lorok, (2) kualitas digitalisasi atau penataan pada kapal dan (3) kualitas perwakilan penjualan barang dan muatan dalam pelabuhan. Penelitian ini menunjukkan bahwa kemampuan untuk memperbaiki sistem operasional sesuai dalam standar prosedur pada kapal yang masuk dan keluar untuk memenuhi syarat-syarat yang berlaku di Pelabuhan Tambak Lorok Semarang.
\end{abstract}

Kata Kunci: sistem layanan, Pelabuhan Tambak Lorok, dokumen kapal.

\section{PENDAHULUAN}

Negara Indonesia adalah negara yang menurut sejarah budaya dan pada zaman kerajaan merupakan negara Bahari. Negara Indonesia dengan kepulauan terluas meliputi laut terluas, pulau terbanyak, dan pantai terpanjang kedua di dunia. Atas dasar tersebut, Indonesia saat ini memiliki pelabuhan modern dan juga pelabuhan untuk pelayaran rakyat. Pelabuhan rakyat pada umumnya identik dengan kapal kayu tradisional yang dioperasikan oleh pelaut dari warga lokal dengan manajemen sederhana.

Pentingnya Surat Persetujuan Berlayar secara khusus diatur dalam undangundang ini yang wajib dimiliki setiap kapal yang berlayar dan dikeluarkan oleh Syahbandar yang merupakan pejabat pelayaran rakyat. Pada perkembangannya, saat ini keberadaan pelayaran rakyat itu telah mulai terpinggirkan oleh beroperasinya kapal-kapal modern mengakibatkan pelayaran lokal yang menggunakan kapal kayu yang memiliki gros ton kecil mulai tersingkirkan, serta kebijakan dari pemerintah yang mendukung pada operasional kapal modern menyertainya dalam kebijakan pemerintah, sehingga mengalami keterpurukan pada warga lokal (Indrawasih., 2018).

Tuntutan bisnis global menyebabkan pelayaran rakyat saat ini terpinggirkan. Pelabuhan merupakan tempat bersandarnya kapal dan tempat naik turunnya penumpang juga tempat bongkar dan muata barang, sehingga pelabuhan merupakan pintu gerbang perekonomian rakyat yang akan memajukan perekonomian suatu daerah. (Romadhon, Yusuf., et., all. 2017). Pelabuhan juga dilengkapi dengan fasilitas keselamatan pelayaran dan penghubung antar moda 
transportasi laut darat dan kereta api. Pelayaran rakyat masih dibutuhkan, sebab daerah terpencil yang tidak dilintasi kapal besar otomatis masih bergantung pada kapal ukuran kecil semacam KLM maupun PLM untuk menyalurkan bahan pokok dan sekunder dalam pendistribusiannya. Selain itu ada pula dermaga yang tidak bisa disandari kapal besi atau pelabuhan dangkal.

Pemerintah berkomitmen untuk memoderenisasi dan meningkatkan keselamatan dan keamanan pelayaran lokal yang dikelola dan dioperasionalkan oleh rakyat dengan tetap mempertimbangkan kearifan lokal dengan pengembangan ini juga dapat meningkatkan keefektifan dan kinerja dalam pelabuhan rakyat. Kurang terkoordinirnya perusahaan rakyat yang ada di pelabuhan-pelabuhan tradisional mempunyai dampak pada pendataannya perusahaan yang di kelola oleh rakyat tersebut juga belum menyeluruh, sehingga secara birokrasi kapal-kapal yang beroperasi masih banyak yang masuk di dalam daftar Kantor Syahbandar dan Otoritas Pelabuhan (KSOP), sehingga kapal tersebut beroperasi secara legal. Di sinilah yang perlu kita benahi secara perlahan-lahan supaya administrasi menjadi tertib.

Adapun tujuan dari penelitian ini adalah untuk mengkaji sistem pelabuhan rakyat dan system dokumen kapal dan dokumen muatan di Pelabuhan Rakyat Tambak Lorok Semarang. Beberapa masalah utama pada pelabuhan-pelabuhan rakyat seperti di Pelabuhan Rakyat Tambak Lorok Semarang yaitu sedimentasi tinggi, rendahnya laju pembongkaran pada dermaga, akses transportasi darat yang kurang baik, minimnya dana pembangunan, kurang berfungsinya tempat berlindung kapal, kumuh, kendala pembebasan lahan, tidak ada lahan parkir, dan fasilitas pelabuhan yang buruk (Sholeh., 2018). Adanya pelabuhan rakyat di sepanjang perairan seharusnya berperan dalam kegiatan bongkar muat barang sehingga kapalkapal yang datang di wilayah perairan tidak menunggu terlalu lama untuk melakukan bongkar muat (Emma., 2019).

Dengan tidak tersedianya sarana perhubungan laut yang memadai dapat menjadi penghambat perkembangan ekonomi di suatu wilayah. Untuk itu perlunya suatu perencanaan dan pembangunan fasilitas pelabuhan yang memadai guna mendukung peningkatan ekonomi disuatu wilayah tersebut. (Devina, Clara., et., all. 2017) Kebanyakan kapal yang datang di perairan adalah kapal dengan tonase besar yang tidak dapat dapat dilayani oleh pelabuhan rakyat. Untuk itu, pemilik pelabuhan perlu menambah panjang dermaga sehingga dapat melayani kapal yang lebih besar. Pengaruh lain dari sepinya kegiatan bongkar muat di pelabuhan rakyat adalah ekonomi masyarakat di sekitar pelabuhan. (Emma., 2019)

\section{METODE}

Lokasi penelitian ini adalah Pelabuhan Rakyat Tambak Lorok Semarang. Gambar di bawah ini adalah lokasi penelitian Pelabuhan Rakyat Tambak Lorok Semarang yang menjadi salah satu pelabuhan rakyat yang masih butuh perhatian pemerintah untuk dilakukan penataan lokasi maupun sistem administrasi yang selama ini belum berjalan sesuai dengan aturan pemerintah. Untuk jenis penelitian, peneliti menggunakan pendekatan kualitatif, yaitu penelitian yang jenis datanya kualitatif, berupa penyataan, kalimat, dan dokumen. Metode yang digunakan adalah metode penelitian lapangan (field research). Penelitian lapangan adalah sebuah penelitian yang sumber data dan proses penelitiannya menggunakan kancah atau lokasi tertentu. Data penelitian yang terkumpul kemudian dianalisis dengan 
melakukan pemeriksaan secara konsepsional atau suatu pernyataan, sehingga dapat diperoleh kejelasan arti. Penelitian ini menggunakan pendekatan kualitatif deskriptif, yaitu penelitian yang berusaha mendeskripsikan suatu gejala, peristiwa, kejadian yang terjadi pada saat sekarang.

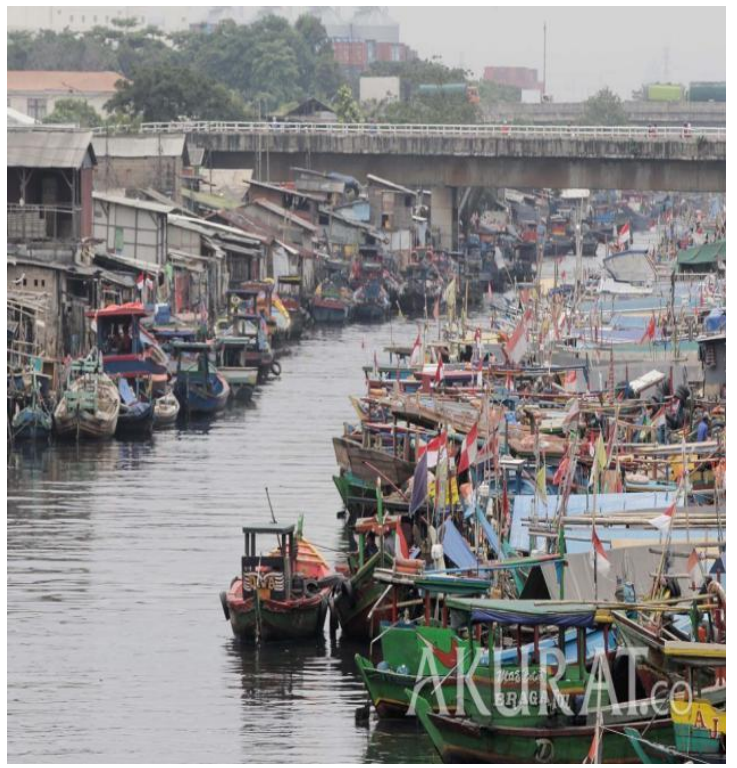

Gambar Pelabuhan Rakyat Tambak Lorok Semarang

\section{HASIL DAN PEMBAHASAN}

Pada dasarnya setiap armada pelayaran akan menyinggahi suatu pelabuhan dengan tujuan tertentu seperti bongkar muat barang. Sebelum mengadakan kegiatan, suatu kapal terlebih dahulu harus diadakan pemeriksaan oleh pihak atau instansi yang berwenang dalam memeriksa semua dokumen yang berhubungan dengan keselamatan dan keamanan pelayaran. Begitu pula dengan penyelesaian dokumen kapal dalam pelayanan keagenan kapal. Setiap angkutan yang menggunakan media air dan berlayar di atasnya pasti singgah di pelabuhan untuk melakukan bongkar muat. Rencana kedatangan dan keluarnya harus dikoordinasikan dengan Port Authority setempat, dalam hal ini adalah KSOP Semarang. Kapal erat kaitannya dengan pengurusan dokumen-dokumen kapal mulai dari awal kedatangan kapal, pada saat kapal berada di pelabuhan hingga kapal berangkat menuju pelabuhan berikutnya. Penyelesaian dokumen juga penting dengan penggunaan sistem online ini diharapkan dapat meningkatkan pelayanan kapal yang cepat, terpercaya, transparan dan terstandar sehingga dapat meminimalkan biaya penanganan kapal di pelabuhan mampu meningkatkan kinerja penanganan atas kegiatan perdagangan dalam proses penyelesaian dokumen kapal. Dari survei yang dilakukan di PT. PELINDO III (Persero) Semarang, didapatkan bahwa pada pengurusan administrasi kapal terdapat beberapa dokumen yang harus dilengkapi sebelum kapal datang dan tiba, hingga kapal akan diberangkatkan kembali diantaranya:

a. Sertifikat atau surat yang harus ada di atas Kapal

1. Nama kapal

2. Tanda panggilan

3. Tempat pendaftaran

4. Tanda Pendaftaran

5. Ukuran (panjang $\mathrm{x}$ lebar $\mathrm{x}$ dalam)

6. Tonase kotor

7. Tonase bersih

8. Tahun pembangunan

9. Penggerak utama

10. Merek TK/KW

11. Bahan utama kapal

12. Jumlah geladak

13. Jumlah baling-baling

Dengan penjelasan terperinci sebagai berikut :

a) Surat Ukur Internasional (1969)

Surat Ukur Internasional= International Tonnage Certifiate (1969) diterbitkan berdasarkan ketentuan-ketentuan Konvensi Internasional Tentang Pengukuran Kapal, 1969 oleh Pemerintah Indonesia. Yang tercantum pada surat ukur:

1) Nama kapal

2) Tanda atau huruf pengenal

3) Tempat pendaftaran 
4) Tanggal peletakan lunas atau tanggal dimana kapal mengalami perubahan atau perombakan besar

5) Ukuran-ukuran pokok: panjang, lebar, dalam

6) Isi kapal: tonase kotor (gross tonnage) dan tonase bersih (net tonnage)

7) Ruang-ruang yang termasuk dalam tonase kotor

8) Ruang-ruang yang termasuk dalam tonase bersih

9) Panjang kapal seluruhnya

10) Tanda Selar dan di mana dipasang

b) Sertifikat untuk keselamatan kapal barang yaitu:

1) Sertifikat Keselamatan Perlengkapan $=$ Cargo Ship Safety Equiment Certificate

2) Sertifikat Keselamatan Konstruksi $=$ Cargo Ship Safety Contruction Certificate

3) Sertifikat Keselamatan Radio = Cargo Ship Safety Radio Certificate

Pada Sertifikat Keselematan Perlengkapan Kapal Barang tercantum antara lain jenis kapal. Kemudian dinyatakan bahwa kapal telah diperiksa sesuai dengan persyaratan perundangundangan.

Bahwa

pemeriksaan

menunjukkan (antara lain), kapal memenuhi persyaratan konvensi dengan sistem dan sarana keselamatan kebakaran serta bagan pengendali kebakaran, sarana dan pelengkapan penyelamatan diri dari sekoci penolong, rakit penolong dan sekoci penyelamat dilengkapi sesuai dengan peraturan perundang-undangan, kapal dilengkapi dengan sarana pelempar tali dan instalasi radio yang digunakan pada saat penyelamatan diri sesuai dengan peraturan perundang-undangan, kapal memenuhi persyaratan peraturan perundangan-undangan yang berkaitan dengan perlengkapan navigasi pelayaran, sarana embarkasi pandu dan publiksai nautika. Kemudian terdapat lampiran perlengkapan yang berisi uraian perlengkapan keselamatan jiwa, tentang sistem dan perlengkapan navigasi, dll.

c) Pada Sertifikat Keselamatan Konstruksi Kapal Barang terdapat pernyataan (antara lain):

1) Bahwa kapal telah diperiksa sesuai dengan persyaratan peraturan perundang-undangan

2) Pemeriksaan menunjukkan bahwa kondisi bangunan, permesinan dan perlengkapan sebagaimana ditetapkan dalam peraturan di atas memuaskan dan kapal memenuhi persyaratan

d) Pada Sertifikat Keselamatan Radio Kapal Barang tertera (antara lain) daerah pelayaran kapal. Kemudian dinyatakan:

1) Bahwa kapal telah diperiksa sesuai dengan peraturan Perundang-undangan

2) Pemeriksaan menunjukkan bahwa

3) Kapal memenuhi persyaratan yang berkaitan dengan instalasi radio

4) Fungsi instalasi radio yang digunakan pada sarana penyelamatan diri memenuhi persyaratan peraturan Perundang-undangan

e) Sertifikat klasifikasi terdiri atas:

1) Sertifikat Klasifikasi Mesin = Certificate of Classification for Machinery 
2) Sertifikat Klasifikasi Lambung $=$ Certificate of Classification of Hull

f) Sertifikat Garis Muat Internasional (1966)

Sertifikat Garis Muat Internasional $(1966)=$ International Load Line Certificate (1966) diterbitkan berdasarkan ketentuan Konvensi Intenasional tentang Garis Muat (1966).

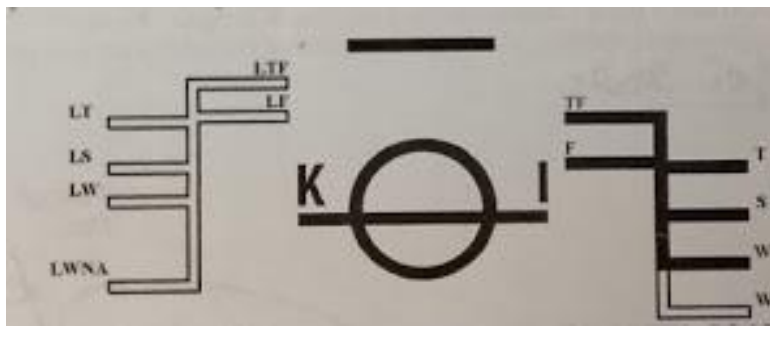

b. Dokumen yang di siapkan dalam memuat barang maupun membongkar

1) Manifest

Surat yang merupakan suatu daftar barang-barang/muatan yang telah dikapalkan. Di mana daftar tersebut berisi: nama kapal, pelabuhan muat dan pelabuhan tujuan, nama nakhoda, tanggal, No. B/L Pengirim (shipper), penerima (consignees), tanda (mark), jumlah/banyaknya (quantity), jenis barang/muatan (description of goods), isi \& berat (volume \& weight) dan keterangan jika ada. Dibuat oleh perusahaan pelayaran.

2) Bill Of Lading

Merupakan surat persetujuan pengangkutan barang antara pengirim (shipper) dan perusahaan pelayaran (Owner) dengan segala konsekuensinya yang tertera pada surat tersebut. Juga dapat merupakan surat kepemilikan barang sebagaimana yang tertera dalam surat tersebut dan oleh karenanya dapat diperjual belikan sehingga Bill of Lading ini juga merupakan surat berharga.

3) Tally Sheet

Suatu daftar/catatan penghitungan jumlah/banyaknya muatan yang diterima atau muatan yang dibongkar oleh kapal. Penghitungan dilakukan oleh Tally Clerk dan di syahkan/diketahui oleh Mualim I.

4) Letter of Indemnity/Letter $O f$ Guarantee

Adalah surat jaminan yang dibuat oleh Shipper untuk memperoleh clean B/L, di mana Shipper akan bertanggung jawab apabila timbul Claim atas barang tersebut.

5) Delivery Order

Suatu surat yang menyatakan kepemilikan atas barang atau muatan. Di mana D/O dapat diperoleh dengan menukarkan $\mathrm{B} / \mathrm{L}$ miliknya.

6) Statement Of Fact

Laporan pelaksanaan kegiatan bongkar/muat mulai dari awal hingga selesai kegiatan.

7) Stowage Plan

Merupakan gambaran informasi kondisi muatan yang berada dalam ruang muat baik mengenai letak, jumlah dan berat muatan sesuai Consignment Mark bagi masingmasing pelabuhan tujuannya.

8) Hatch List

Daftar muatan yang berada dalam palka yang bersangkutan.

9) Discharging List

Daftar bongkaran muatan pada suatu pelabuhan tertentu.

10) Damage Report

Merupakan suatu surat berita acara kerusakan muatan yang terjadi diatas kapal sehubungan tanggung jawab pihak Carrier.

11) Marine Note Of Sea Protest

Merupakan suatu Berita Acara atas kerusakan muatan diluar 
kemampuan manusia. Dibuat oleh

Nakhoda dan disahkan oleh Notaris.

12) Notice Of Readiness

Suatu surat yang dibuat oleh Nakoda yang menyatakan bahwa kapal telah siap untuk melaksanakan kegiatan pembongkaran atau pemuatan. Semua dokumen diatas diperlukan dalam pemberangkatan muatan dan juga menjadi syarat kelegalan kapal tersebut. Namun pada pelaksanaannya Dokumen minimun yang wajib ada berkaitan dengan Muatan di suatu Kapal adalah Manifest dan Bill of Lading.

c. Dokumen pengurusan Surat Ijin Berlayar

1) Surat Permohonan

2) Kapal telah melakukan lapor tiba, daftar awak kapal, daftar muatan (manifest) dari pelabuhan asal

3) Daftar pemeriksaan kapal sesuai PM.82 tahun 2014, surat pernyataan Nahkoda (master sailing declaration) sesuai PM . 82 tahun 2014.

4) Daftar awak kapal dan sertifikat dokumen kesehatan pengawakan minimum (Minimum safe Manning)

5) Bukti surat perintah kerja pandu (SPK ) bagi kapal 500 GT.

6) Bukti pembayaran PNBP dan VTS

7) Bukti pembayaran jasa kepelabuhan

8) Bukti pembayaran jasa labuh dari Otoritas Pelabuhan

9) Laporan Kedatanagn dan keberangkatan kapal dari Bidang Lala dan Usaha Kepelabuhan

10) Memorandum dokumen / surat surat kapal

11) Daftar Muatan Kapal

12) Bukti rencana pemuatan (Stowage Plan)
13) Perhitungan Stabilitas (Stability Calculation)

14) Bagi kapal asing ditambah dengan melampirkan Port State Control ( PSC), Flag State Control, Inward Manifest, Outward Manifest, Imigration Clearance.

\section{SIMPULAN}

Dalam penataan sistem pelabuhan rakyat di Pelabuhan Tambak Lorok Semarang menunjukna bahwa pelabuhan rakyat di sana masih sangat kurang dalam pelayanannya, koordinasi dalam pendataan perusahaan yang di data oleh pemerintah setempat masih kurang, dan di tambah dengan warga lokal yang mempunya kapal masih belum bisa memenuhi semua syarat atas kepelikikan kapal di karenakan kendala dalam biaya dan kapal yang di gunakan tergolong dengan kapal layar motor yang hanya memiliki gross ton yang kecil, tidak diperuntukan dalam pelayaran jauh. Dalam penataan di pelabuhan rakyat di Pelabuhan Tambak Lorok Semarang masih tergolong belum teratur dan masih banyak yang harus dibenahi kembali.

\section{DAFTAR PUSTAKA}

Devina, Clara., et., all. 2017. "Perencanaan Dermaga Pelabuhan Rakyat Samber Papua". Jurnal Karya Teknik Sipil, Volume 6, No 4, Hal 309-318.

Indrawasih, Ratna. 2018. "Pelayaran Rakyat di Kabupaten Maluku Tengah yang Terpinggirkan dan Respon Stakeholder". Jurnal Transportasi Laut, Volume 20, 4054.

Peraturan Menteri Perhubungan RI No. PM. 82 Tahun 2014. Tentang Tata Cara Penerbitan Surat Persetujuan Berlayar.

Peraturan Menteri Perhubungan RI No. PM. 39 Tahun 2017. Tentang Pendaftaran Kebangsaan Kapal. 
Romadhon, Yusuf., et., all. 2017. "Pelayaran Rakyat Dalam Perspektif Sistem Logistik Nasional". Jurnal Logistik Indonesia, Volume 01, Nomor 01.

Ruhaidani, Emma. 2019. "Kajian Peranan Pelabuhan Rakyat Di Teluk Kumai”. Juranal Teknik Sipil, Volume 1, No 2.

Sholeh, Moh, Nur. 2018. "Manajemen Risiko Pelabuhan Rakyat Guna Mendukung Rantai Pasok Nasional". Jurnal Rekayasa Sipil, Volume 14, No 02.

Undang-Undang Nomor 17 Tahun 2008. Tentang Pelayaran. 